\title{
English Plantain Pollen IgE Measurement
}

National Cancer Institute

\section{Source}

National Cancer Institute. English Plantain Pollen IgE Measurement. NCI Thesaurus.

Code C130084.

A measurement of the English plantain (Plantago lanceolata) pollen IgE in a biological specimen. 